\title{
EPIDEMIOLOGICAL AND CLINICAL CHARACTERISTICS OF PATIENTS WITH PEMPHIGUS TREATED IN BIAEYSTOK IN 2001-2018
}

\author{
EPIDEMIOLOGICZNA I KLINICZNA CHARAKTERYSTYKA PACJENTÓW \\ Z PECHERZYCĄ LECZONYCH W OŚRODKU BIAŁOSTOCKIM W LATACH 2001-2018
}

${ }^{1}$ Medical University of Bialystok Department of Dermatology and Venereology, Uniwersytet Medyczny w Białymstoku, Klinika Dermatologii i Wenerologii

\section{ABSTRACT}

BACKGROUND. Pemphigus is a group of potentially fatal dermatological autoimmune disorders. AIM. Analysis of cases of pemphigus vulgaris (PV) and pemphigus foliaceus (PF) newly diagnosed and treated at the Department of Dermatology and Venereology, Medical University of Białystok, North-east Poland in years 2001-2018.

MATERIAL AND METHODS. A retrospective analysis and comparison of sociodemographic, epidemiological and clinical characteristics of PV and PF patients, including: age, gender, residency, initial severity of skin lesions, involvement of mucous membranes, co-morbidities and their treatment, efficacy of therapy.

RESULTS. Sixty-two new cases - 41 (66.13\%) of PV and 21 (33.87\%) of PF were diagnosed. The average age of PV patients was $54.85 \pm 12.35$ years and those of $\mathrm{PF}-63.81 \pm 31.52$ years, $\mathrm{P}<0.05$. Females constituted $75.61 \%$ and $61.90 \%$ in PV and PF group, respectively. Majority of patients with PV were residents of urban and these with PF - of rural areas (70.73\% and $66.67 \%$, respectively). On admission, 14 patients with PV (34.15\%) and 11 with PF (52.38\%) had more than 30\% of body surface area involved. In $22(53.66 \%)$ PV mucous membrane (oropharyngeal cavity) was involved. Ten (24.39\%) patients with PV and 12 (57.14\%) - with PF had more than one concomitant disorder $(\mathrm{P}<0.05)$. In treatment prednisone in monotherapy or with additional immunosuppressive agent was mainly used. The disease relapsed within three years after achieving clinical and immunological remission in $29.27 \%$ of $\mathrm{PV}$ and in $38.10 \%$ of PF patients.

CONCLUSIONS. PF patients are older than PV ones, more frequently live in rural areas, have more comorbidities. Females constitute majority of pemphigus patients. The disease may relapse in about one third of patients. Because of frequent comorbidities, also these related to pemphigus treatment, patients with pemphigus require complex and multispecialistic medical care.

Key words: pemphigus vulgaris, pemphigus foliaceus, epidemiology, comorbidities, medications

\section{STRESZCZENIE}

WSTĘP. Pęcherzyce są grupą potencjalnie śmiertelnych autoimmunologicznych schorzeń dermatologicznych.

CEL. Analiza przypadków pęcherzycy zwykłej (pemphigus vulgaris - PV) i pęcherzycy liściastej (pemphigus foliaceus - PF) zdiagnozowanych i leczonych w Klinice Dermatologii i Wenerologii Uniwersytetu Medycznego w Białymstoku w latach 2001-2018.

MATERIAŁ I METODY. Retrospektywna analiza i porównanie danych socjodemograficznych, epidemiologicznych i klinicznych pacjentów z PV i PF, z uwzględnieniem wieku, płci, miejsca zamieszkania, rozległości zmian skórnych, zajęcia błon śluzowych, schorzeń współistniejących i przyjmowanych leków, skuteczności terapii.

WYNIKI. Rozpoznano 62 nowe przypadki pęcherzycy - 41 (66,13\%) PV and 21 (33,87\%) PF. Średni wiek pacjentów z PV wynosił 54,85 $\pm 12,35$ roku a z PF $-63,81 \pm 31,52$ roku $(\mathrm{p}<0,05)$. Kobiety stanowiły odpowiednio $75,61 \%$ i $61,90 \%$ w grupie PV i PF. Większość pacjentów z PV mieszkało w miastach, a z PF - na wsi (odpo- 
wiednio 70,73\% i 66, 67\%). Ponad 30\% powierzchni skóry zajętej zmianami chorobowymi miało 14 (34,15\%) pacjentów z PV i $11(52,38 \%)$ z PF. Zajęcie błon śluzowych jamy ustnej stwierdzono u $22(53,66 \%)$ pacjentów z PV. Więcej niż jedno schorzenie współistniejące z pęcherzycą miało 10 pacjentów $(24,39 \%)$ z PV i 12 (57,14\%) $\mathrm{z} P \mathrm{PF}, \mathrm{p}<0,05$. W leczeniu stosowano głównie prednizon w monoterapii lub razem $\mathrm{z}$ innymi lekami immunosupresyjnymi. Choroba nawróciła w ciągu trzech lat po osiągnięciu remisji klinicznej i immunologicznej u 29,27\% pacjentów z PV i $38,10 \%$ - z PF.

WNIOSKI. Pacjenci z PF są starsi niż z PV, częściej mieszkają na terenach wiejskich, mają więcej schorzeń współistniejących. Kobiety stanowią większość chorych z pęcherzycą. U jednej trzeciej pacjentów choroba może nawrócić. Ze względu na częste inne schorzenia, w tym powiązane z leczeniem pęcherzycy, pacjenci ci wymagają złożonej i wielospecjalistycznej opieki medycznej.

Słowa kluczowe: pęcherzyca zwykła, pęcherzyca liściasta, epidemiologia, choroby wspótistniejace, leki

\section{INTRODUCTION}

Pemphigus is a group of autoimmune blistering disordersaffecting skinwith possiblemucousmembrane involvement (1). The acantholysis and bullae formation result from production of autoantibodies against desmosomal components, mainly against desmoglein (Dgl) 1 and 3 (2). Pemphigus vulgaris (mucosal and mucocutaneous type) and pemphigus foliaceus are two the most common forms $(1,2)$. Studies indicate that pemphigus vulgaris and foliaceus can be triggered, exacerbated or sustained by several exogenous factors, including, among others, medications, co-morbidities, sun exposure or nutrients (2-4).

Department of Dermatology and Venereology, Medical University of Bialystok is the tertiarycare medical centre for diagnosis and treatment of autoimmune skin disorders, including pemphigus. In years $2001-2015,75 \%$ of all pemphigus cases in Podlaskie Province (North-East Poland) were diagnosed at the Department (5).

The aim of our study was to analyse sociodemographic, epidemiological and clinical characteristics of patients with pemphigus vulgaris and pemphigus foliaceus newly diagnosed and treated at the Department of Dermatology and Venereology Medical University of Bialystok in years 2001 - 2018.

\section{MATERIAL AND METHODS}

A retrospective analysis and comparison of data of patients with newly diagnosed pemphigus vulgaris and pemphigus foliaceus was conducted. The diagnosis of pemphigus was confirmed with direct and indirect immunofluorescence studies (DIF and IIF, respectively), with titration of circulating anti-Dgl antibodies bound to monkey (Dg1 3) and guinea pig (Dgl 1) oesophagus. DIF and IIF are the mainstay and standard laboratory diagnostic methods of autoimmune blistering disorders $(1,6)$. The method has not changed over the period studied. Analysis of patients' gender, age, residency, time between the onset of lesions and

\section{WSTĘP}

Pęcherzyce są grupą autoimmunologicznych chorób skóry z częstym zajęciem błon śluzowych (1). Akantoliza i tworzenie pęcherzy jest wynikiem produkcji autoprzeciwciał skierowanych przeciwko komponentom desmosomalnym, przede wszystkim desmogleinie (Dgl) 1 i 3 (2). Najczęstszymi postaciami klinicznymi jest pęcherzyca zwykła (w odmianie śluzówkowej i śluzówkowo-skórnej) i pęcherzyca liściasta $(1,2)$. Badania wskazują, że pęcherzyce mogą być sprowokowane, zaostrzane lub podtrzymywane przez różne czynniki, takie jak leki, schorzenia współistniejące, promieniowanie UV lub czynniki żywieniowe (2-4).

W Klinice Dermatologii i Wenerologii Uniwersytetu Medycznego w Białymstoku diagnozowana i leczona jest większość pacjentów z autoimmunologicznymi schorzeniami skóry w województwie podlaskim, w tym z pęcherzycami (75\% wszystkich przypadków pęcherzycy w regionie w latach 2001-2015) (5).

Celem pracy jest analiza danych socjodemograficznych, epidemiologicznych i klinicznych pacjentów z pęcherzycą zwykłą i liściastą nowo rozpoznanych i leczonych w Klinice Dermatologii i Wenerologii UMB w latach 2001-2018.

\section{MATERIAŁ I METODY}

Dokonano retrospektywnej analizy oraz porównania danych pacjentów z nowo zdiagnozowaną pęcherzycą zwykłą i liściastą. Rozpoznanie pęcherzycy potwierdzono dodatnimi wynikami badania immunofluorescencyjnego bezpośredniego (tkankowego) oraz pośredniego z oceną miana krążących przeciwciał przeciwko Dgl związanych na przełyku małpy (Dgl 3) i świnki morskiej (Dgl 1). Badania te stanowią standard w diagnostyce laboratoryjnej autoimmunologicznych chorób pęcherzowych $(1,6)$. W powyższym okresie metodyka badań immunofuorescencyjnych pozostawała bez zmian. Poddano analizie płeć, wiek pacjentów, miejsce zamieszkania, czas od pojawienia się 
first hospitalization was performed. We analysed initial severity of skin lesions and mucous membrane involvement, treatment and its effectiveness in achievement of clinical and immunological remission. We have also analysed concomitant disorders at the onset of pemphigus and their treatment, and the disorders newly diagnosed during the treatment of pemphigus.

Clinical remission was defined as ceasing of new blisters formation and healing of erosions and immunological remission - as absence of antidesmoglein circulating antibodies in two consecutive serum samples taken six month apart.

Statistical analysis was performed using TIBCO Statistica software version 13.3 (TIBCO Software Inc. Palo Alto, CA, USA). The level of significance was set at $P=0.05$. The study protocol was approved by the Ethics Committee of the Medical University of Bialystok, Poland.

\section{RESULTS}

In years $2001-2018,62$ new cases of pemphigus were diagnosed and treated at the Department: 41 (66.13\%) - of pemphigus vulgaris (PV) and 21 (33.87\%) - of pemphigus foliaceus (PF). Number of cases varied from one (in 2005 and 2015) to six (in 2001 and 2014). No clear trend in the number of cases was noticed in years studied. The follow-up period ranged from one year to 16 years (mean value 2.91 years).

In PV group 10 patient were males and 31 - females (24.39\% and $75.61 \%$, respectively), in $\mathrm{PF}$ group eight patients were males and 13 females $(38.10 \%$ and $61.90 \%$, respectively). The average age of PV patients was $54.85 \pm 12.35$ years (range: 31 - 85 years) and those of $\mathrm{PF}-63.81 \pm 31.52$ years (range: $43-83$ years), $\mathrm{P}<0.05$ (Table I). The average age of males was $56.17 \pm 14.33$ years (range: $35-80$ years) and of females $-58.59 \pm 13.04$ years (range: $31-85$ years), $\mathrm{P}>0.05$. objawów do pierwszej hospitalizacji, nasilenie zmian skórnych i zajęcie błon śluzowych, zastosowane leczenie i jego skuteczność w osiągnieciu remisji klinicznej i immunologicznej, a ponadto schorzenia współistniejące przed rozpoznaniem pęcherzycy i przyjmowane $\mathrm{z}$ ich powodu leki oraz schorzenia zdiagnozowane w trakcie leczenia.

Remisję kliniczna zdefiniowano, jako zaprzestanie tworzenia nowych pęcherzy i wygojenie nadżerek, remisję immunologiczną - jako brak krążących przeciwciał w dwóch kolejnych badaniach surowicy w odstępie sześciu miesięcy.

Analizę statystyczną przeprowadzono przy pomocy programu TIBCO Statistica wersja 13.3 (TIBCO Software Inc. Palo Alto, CA, USA). Poziom istotności ustalono przy $\alpha=0.05$. Badanie uzyskało zgodę Komisji Bioetycznej UMB.

\section{WYNIKI}

W latach 2001-2018 zdiagnozowano i leczono w Klinice 62 nowych pacjentów z pęcherzycą: 41 $(61,13 \%)$ z pęcherzycą zwykłą (pemphigus vulgaris - PV) i $21(33,87 \%)$ z pęcherzycą liściastą (pemphigus foliaceus - PF). Liczba przypadków wynosiła od jednego (w roku 2005 i 2015) do sześciu (w roku 2001 i 2014). Nie odnotowano wyraźnego trendu w liczbie przypadków. Okres obserwacji chorych wynosił od jednego roku do 16 lat (średnio 2,91 roku).

W grupie pacjentów z PV było 10 mężczyzn i 31 kobiet (odpowiednio: 24,39\% i 75,61\%), w grupie pacjentów z PF - ośmiu mężczyzn i 13 kobiet (odpowiednio: $38,10 \%$ i $61,90 \%$ ). Średni wiek pacjentów z PV wynosił $54,85 \pm 12,35$ roku (od 31 do 85 lat) a z PF - 63,81 $\pm 31,52$ roku (od 42 do 83 lat), $p<0,05$ (Tabela I). Średni wiek wszystkich mężczyzn wynosił $56,17 \pm 14,33$ (od 35 do 80 lat) a kobiet $-58,59 \pm 13,04$ roku (od 31 do 85 lat), $\mathrm{p}>0,05$.

Table I. Age of male and female patients with pemphigus vulgaris and pemphigus foliaceus (years) Tabela I. Wiek pacjentów i pacjentek z pęcherzycą (w latach)

\begin{tabular}{|c|c|c|c|}
\hline & $\mathrm{PV}$ & $\mathrm{PF}$ & P value \\
\hline Males $(\mathrm{N}=18)$ & $\mathrm{N}=41$ & $\mathrm{~N}=21$ & $>0.05$ \\
\hline Females $(\mathrm{N}=44)$ & $50.80 \pm 13.10$ & $62.88 \pm 13.63$ & 0.03 \\
\hline
\end{tabular}

PV - pemphigus vulgaris, $\mathrm{PF}$ - pemphigus foliaceus

Twenty-nine patients with PV and seven with PF were residents of urban areas $(70.73 \%$ and $33.33 \%$, respectively, $\mathrm{P}<0.05$ ), while 12 patients with $\mathrm{PV}$ and 14 - with PF were residents of rural areas (all were farmers, $29.27 \%$ and $66.67 \%$, respectively, $\mathrm{P}<0.05$ ).
Dwudziestu dziewięciu pacjentów z PV i siedmiu z PF mieszkało w miastach (odpowiednio: 70,73\% i $33,33 \%, p<0.05$ ), a 12 i $14 \mathrm{w}$ tych grupach - na terenach wiejskich(odpowiednio: $29,27 \%$ i $66,67 \%$, $\mathrm{p}<0,05$; wszyscy zajmowali się rolnictwem). 
The time between the beginning of the disease and the admission to the Department and making diagnosis was less than one month in three $(8.33 \%)$ patients leaving in urban areas and in four $(15.38 \%)$ - leaving in rural areas $(\mathrm{P}>0.05)$. Fourteen $(38.89 \%)$ and $11(42.31 \%)$ patients from urban and rural areas, respectively, were admitted more than six months from the onset of disease.

The severity of clinical picture on the first admission is presented in Table II. In 22 (53.66\%) patients with PV mucous membrane (oral cavity) together with skin were involved. Patients with mucous membrane involvement (PV group) were admitted more frequently in less than six months since the onset of the disease than without it $(\mathrm{N}=18,43.90 \%$ and $\mathrm{N}=6$, $14.63 \%$, respectively, $\mathrm{P}<0.05$ ). There was no correlation between the mucous membrane involvement and the size of skin involvement $(\mathrm{R}=-0.05, \mathrm{P}>0.05)$.
Czas od wystąpienia pierwszych mian do hospitalizacji i postawienia rozpoznania wynosił poniżej miesiąca u trzech pacjentów żyjących w miastach $(8,33 \%)$ i czterech - mieszkających na wsi $(15,38 \%), p>0,05$. Czternastu pacjentów z miast (38,89\%) i $11(42,31 \%)$ $\mathrm{z}$ terenów wiejskich głosiło się do szpitala po ponad sześciu miesiącach od powstania zmian ( $\mathrm{p}>0,05)$.

Nasilenie zmian podczas pierwszej hospitalizacji przedstawiono w Tabeli II. U 22 (54,66\%) pacjentów z PV zajęcie błon śluzowych jamy ustnej współistniało ze zmianami skórnymi. Pacjenci z PV, u których występowały zmiany w obrębie błon śluzowych częściej zgłaszali się do Kliniki w czasie krótszym niż sześć miesięcy, niż pacjenci bez zmian śluzówkowych (odpowiednio: $n=18,43,90 \%$ i $n=6,14,63 \%, p<0,05)$.

Table II. The severity of clinical picture on the first admission to the Department Tabela II. Nasilenie zmian przy pierwszej hospitalizacji

\begin{tabular}{|c|c|c|c|c|}
\hline & & $\begin{array}{c}\mathrm{PV} \\
\mathrm{N}=41\end{array}$ & $\begin{array}{c}\mathrm{PF} \\
\mathrm{N}=21\end{array}$ & $\mathrm{P}$ value \\
\hline \multirow{4}{*}{$\begin{array}{c}\text { Skin area involved, } \\
\mathrm{N}(\%)\end{array}$} & $\begin{array}{c}0 \% \text { - only mucosal } \\
\text { lesions }\end{array}$ & $9(21.95)$ & 0 & NA \\
\hline & $<10 \%$ & $8(19.51)$ & $5(23.81)$ & $>0.05$ \\
\hline & $10-30 \%$ & $10(24.39)$ & $5(23.81)$ & $>0.05$ \\
\hline & $>30 \%$ & $14(34.15)$ & $11(52.38)$ & $>0.05$ \\
\hline
\end{tabular}

PV - pemphigus vulgaris, PF - pemphigus foliaceus, NA - not applicable

Prednisone alone or with other immunosuppressive agent (cyclophosphamide or azathioprine) was the initial treatment in $40(97.56 \%) \mathrm{PV}$ and in $15(71.43 \%)$ PF patients $(\mathrm{P}>0.05)$. The initial treatment had to be modified, due to lack of appropriate clinical response, in $16(39.02 \%)$ of PV patients and $11(52.38 \%)$ of PF patients $(\mathrm{P}>0.05)$. The entire time of treatment was over 18 months in $28(68.29 \%)$ of $\mathrm{PV}$ and in $10(47.62 \%)$ of $\mathrm{PF}$ patients $(\mathrm{P}>0.05)$. None of patients were treated with rituximab.

The clinical remission, noticed in all patients, was achieved in less than three months in eight (19.51\%) and two $(9.52 \%)$ of PV and PF patients, respectively $(\mathrm{P}>0.05)$. Immunological remission was achieved in less than one year in eight (19.51\%) PV and four (6.45\%) PF patients $(\mathrm{P}>0.05)$. Lack of immunological remission at the end of observation period was notices in one PV patients $(2.44 \%)$ and in five $\mathrm{PF}$ patients $(23.81 \%, \mathrm{P}<0.05)$. The disease relapsed within three years after achieving clinical and immunological remission in 12 (29.27\%) patients with PV and in eight $(38.10 \%)$ - with PF $(\mathrm{P}>0.05)$. In three patients initially diagnosed with $\mathrm{PV}$ the clinical and immunological transmission to PF was observed.
W leczeniu, wyjściowo, stosowano prednizon w monoterapii lub w połączeniu z innym lekiem immunosupresyjnym (cyklofosfamidem lub azatiopryną) u $40(97,56 \%)$ pacjentów z PV i 15 (71,43\%) z PF $(\mathrm{p}>0,05)$. W związku z brakiem poprawy klinicznej leczenie zostało zmodyfikowane u 16 (39,02\%) pacjentów z PV i $11(52,38 \%)$ z PF, p>0,05. Czas leczenia wynosił ponad 18 miesięcy u $28(68,29 \%)$ pacjentów z PV i $10(47,62 \%)$ - z PF, p>0,05. Żaden z pacjentów nie był leczony rytuksymabem.

Remisja kliniczna, którą obserwowano u wszystkich pacjentów, została uzyskana w czasie poniżej trzech miesięcy u ośmiu (19,51\%) chorych z PV i dwóch $(9,52 \%)$ - z PF, $p>0,05$.Remisję immunologiczną uzyskano w czasie krótszym niż jeden rok u ośmiu (19,51\%) pacjentów z PV i czterech $(6,45 \%)$ z PF, $p>0,05$. U jednego pacjenta (2,44\%) z PV i pięciu $(23,81 \%)$ z PF nie uzyskano remisji immunologicznej do końca obserwacji $(\mathrm{p}<0,05)$.

U 12 (29,27\%) pacjentów z PV oraz ośmiu (38,10\%) z PF doszło do nawrotu schorzenia w ciągu trzech lat po uzyskaniu remisji klinicznej i immunologicznej $(p>0,05)$. U trzech pacjentek $\mathrm{z}$ rozpoznaną PV doszło 
Concomitant disorders at the onset of pemphigus had $25(60.98 \%)$ PV and $16(76.19 \%)$ PF patients, $\mathrm{P}>0.05$ (Table III). Ten (24.39\%) patients with PV and 12 (57.14\%) - with PF had more than one concomitant disorder $(\mathrm{P}<0.05)$. do przejścia w PF, spełniającą kryteria kliniczne i immunologiczne.

Table III. Concomitant disorders at the onset of pemphigus

Tabela III. Choroby współistniejące w chwili zachorowania na pęcherzycę

\begin{tabular}{|l|c|c|c|}
\multicolumn{1}{|c|}{$\begin{array}{c}\text { Disorder } \\
\mathrm{N}(\%)\end{array}$} & $\begin{array}{c}\mathrm{PV} \\
\mathrm{N}=41\end{array}$ & $\begin{array}{c}\mathrm{PF} \\
\mathrm{N}=21\end{array}$ & P value \\
\hline Arterial hypertension & $11(26.83)$ & $11(52.38)$ & 0.04 \\
\hline Autoimmune thyroid gland disorder & $6(14.63)$ & $2(9.52)$ & $>0.05$ \\
\hline Psychiatric disorders & $4(9.76)$ & $3(14.29)$ & $>0.05$ \\
\hline Diabetes type 2 & $4(9.76)$ & $2(9.52)$ & $>0.05$ \\
\hline Ischaemic heart disease & $2(4.88)$ & $2(9.52)$ & $>0.05$ \\
\hline Peptic ulcer & $3(7.32)$ & $1(4.76)$ & $>0.05$ \\
\hline Cardiac rhythm disturbances & $1(2.43)$ & $4(19.04)$ & 0.02 \\
\hline History of internal organ malignancies & $1(2.43)$ & $4(19.04)$ & 0.02 \\
\hline other & $10(24.39)$ & $6(28.57)$ & $>0.05$ \\
\hline
\end{tabular}

$\mathrm{PV}$ - pemphigus vulgaris, $\mathrm{PF}$ - pemphigus foliaceus

Sixteen (39.02\%) of PV patients and 14 (66.67\%) - with PF have taken prescribed medications at the onset of pemphigus, $\mathrm{P}<0.05$ (Table IV). Nine $(21.95 \%)$ $\mathrm{PV}$ and $10(47.62 \%) \mathrm{PF}$ patients took more than one medication, $\mathrm{P}<0.05$.
W chwili rozpoznania pęcherzycy inne schorzenia współistniejące miało 25 (60,98\%) pacjentów z PV i 16 $(76,19 \%)$ z PF (p>0,05) (Tab. III). Dziesięciu (24,39\%) chorych z PV i 12 (57,14\%) z PF miało więcej niż jedno schorzenie współistniejące $(\mathrm{p}<0,05)$. Szesnastu $(39,02 \%)$ pacjentów z PV i 14 (66,67\%) z PF w chwili rozpoznania pęcherzycy przyjmowało leki $(\mathrm{p}<0,05)$ (Tab. IV). Dziewięciu (21,95\%) i 10 (47,62\%) w odpowiednich grupach przyjmowało więcej niż jeden lek $(\mathrm{p}<0,05)$.

Table IV. Groups of medications taken at the onset of pemphigus

Tabela IV. Grupy leków przyjmowane w chwili zachorowania na pęcherzycę

\begin{tabular}{|l|c|c|c|}
\multicolumn{1}{|c|}{$\begin{array}{c}\text { Medications } \\
\text { N (\%) }\end{array}$} & $\begin{array}{c}\text { PV } \\
\text { N=41 }\end{array}$ & $\begin{array}{c}\text { PF } \\
\text { N=21 }\end{array}$ & P value \\
\hline ACE-inhibitors or ARBs & $7(17.07)$ & $7(33.33)$ & $>0.05$ \\
\hline Diuretics & $5(12.29)$ & $5(23.81)$ & $>0.05$ \\
\hline Beta-blockers & $5(12.29)$ & $8(38.10)$ & 0.01 \\
\hline Calcium-channel blockers & $5(12.29)$ & $1(4.76)$ & $>0.05$ \\
\hline Thyroid gland hormone & $3(7.32)$ & $1(4.76)$ & $>0.05$ \\
\hline Other (including NSAIDs) & $6(14.63)$ & $4(19.05)$ & $>0.05$ \\
\hline
\end{tabular}

PV - pemphigus vulgaris, PF - pemphigus foliaceus, ACE-inhibitors - angiotensin-converting enzyme inhibitors, ARBs - angiotensin II receptor blockers, NSAIDs - non-steroidal anti-inflammatory drugs

Additional disorders during treatment of pemphigus were diagnosed in 24 (58.54\%) PV and $13(61.90 \%)$ $\mathrm{PF}$ patients, $\mathrm{P}>0.05$ (Table V). Among those more than one disorder was diagnosed in $15(62.50 \%)$ and 7 (53.85\%) PV and PF patients, respectively ( $\mathrm{P}>0.05)$.
Podczas leczenia pecherzycy inne nowe schorzenia zdiagnozowano u $24(58,54 \%)$ pacjentów z PV i 13 $(61,90 \%)$ - z PF, p>0,05 (Tab. V). Wśród nich, u 15 $(62,50 \%)$ i $7(53,85 \%)$, w odpowiednich grupach, rozpoznano więcej niż jedno nowe schorzenie $(p>0,05)$. 
Table V. Diseases diagnosed during treatment of pemphigus

Tabela V. Schorzenia nowo zdiagnozowane podczas leczenia pęcherzycy

\begin{tabular}{|l|c|c|c|}
\hline \multicolumn{1}{|c|}{$\begin{array}{c}\text { Disorder } \\
\mathrm{N}(\%)\end{array}$} & $\begin{array}{c}\text { PV } \\
\mathrm{N}=41\end{array}$ & $\begin{array}{c}\text { PF } \\
\mathrm{N}=21\end{array}$ & P value \\
\hline Diabetes & $11(26.83)$ & $6(28.57)$ & $>0.05$ \\
\hline Osteoporosis & $8(19.51)$ & $3(14.29)$ & $>0.05$ \\
\hline Bacterial infections, including furunculosis & $8(19.51)$ & $2(9.52)$ & $>0.05$ \\
\hline Arterial hypertension & $7(17.07)$ & $2(9.52)$ & 0.01 \\
\hline Internal organ malignancy & $3(7.32)$ & $1(4.76)$ & $>0.05$ \\
\hline Anaemia & $2(4.88)$ & $2(9.52)$ & $>0.05$ \\
\hline Glaucoma & $2(4.88)$ & 0 & $>0.05$ \\
\hline Other & $11(26.83)$ & $4(19.05)$ & $>0.05$ \\
\hline
\end{tabular}

$\mathrm{PV}$ - pemphigus vulgaris, $\mathrm{PF}$ - pemphigus foliaceus

\section{DISCUSSION}

PV is considered as the most prevalent type of pemphigus, comprising up to $90 \%$ of all cases of pemphigus. In the present study $\mathrm{PV}$ was also more frequently diagnosed than $\mathrm{PF}$, which is in concordance with several epidemiological studies (4,7-10). However, in a recent study from Northern Finland PF constituted $65 \%$ of 46 pemphigus cases in years $1985-2017$ (11).

Females constituted majority of cases with female to male ratio was 2.44 , which is higher that ratio observed in other studies from European region, in which it ranged from 1.22 to 1.8 (2,9-12). In some recent studies, however, male with pemphigus, especially PF, were more prevalent $(4,7,8,13)$.

The age of PV patients was significantly lower than this of PF patients, mainly due to significantly younger age of females with PV than these with PF. The mean age of onset of pemphigus in majority of European populations is over 50 years (2). Some authors also demonstrated younger age of patients with PV than these with $\mathrm{PF}(4,7,8,10)$. In our study men were younger than females in both groups, similarly to results of a cohort study form Israel (4).

Majority of all patients were residents of urban areas but among PF patients residents of rural areas prevailed, which is in concordance with results of our previous study, comprising pemphigus patients from the whole province (5). Studies on association between the residency and the incidence of pemphigus are extremely rare. Frequent and long-lasting outdoor activity and sun exposure of inhabitants of rural areas can contribute to triggering of pemphigus as UVirradiation is well established factor inducing and aggravating both PV and PF (3). In addition, higher exposure to pesticides and gardening materials may play important role in the inducement of pemphigus (3). Endemic PF in Brasilia, Colombia or Tunisia, a disease of complex and multifactorial aetiology, is
Wyniki naszego badania potwierdzają, że pęcherzyca zwykła jest najczęstszym typem pęcherzycy, może stanowić nawet $90 \%$ przypadków schorzeń z grupy pęcherzyc (4,7-10). W niedawno opublikowanej pracy z regionu Północnej Finlandii to chorzy z pęcherzycą liściastą stanowili aż 65\% z 46 przypadków w latach 1985 - 2017 (11).

Kobiety stanowiły większość przypadków, wskaźnik kobiet do mężczyzn wynosił 2,44 , co jest wartością wyższą niż w innych ośrodkach europejskich (od $1,22: 1$ do $1,8: 1)(2,9-12)$. W niektórych badaniach mężczyźni stanowili większość pacjentów z pęcherzycą, szczególnie pęcherzycą liściastą $(4,7,8,13)$.

Średni wiek chorych na pęcherzyce w populacjach europejskich wynosi powyżej 50 lat (2). Wiek pacjentów z pęcherzycą zwykłą był niższy niż z pęcherzycą liściastą, głównie z powodu niższego wieku pacjentek z pęcherzycą zwykłą niż liściastą. Część autorów również wykazała, że pacjenci z pęcherzycą zwykłą są młodsi niż z pęcherzycą liściastą $(4,7,8,10)$. W naszym badaniu mężczyźni byli młodsi niż kobiety w obydwu grupach.

Większość wszystkich pacjentów było mieszkańcami miast, ale $\mathrm{w}$ grupie chorych $\mathrm{z}$ pęcherzycą liściastą przeważali mieszkańcy wsi, co potwierdza nasze poprzednie obserwację, obejmujące całe województwo (5). Badania dotyczące powiązania miejsca zamieszkania i występowania pęcherzycy są niezwykle rzadkie. Promieniowanie UV jest dowiedzionym czynnikiem mogącym sprowokować pęcherzycę lub zaostrzyć przebieg zarówno pęcherzycy zwykłej, jak i liściastej (3). Częsta i długotrwała ekspozycja na słońce, związana z pracami na wolnym powietrzu mieszkańców terenów wiejskich może zatem przyczynić się do wywołania pęcherzycy. Rolę w indukowaniu pęcherzycy może również odgrywać częsta ekspozycja na pestycydy i inne środki ochrony roślin (3). Endemiczna odmiana pęcherzycy liściastej, będą- 
seen mainly among outdoor workers from rural areas $(2,14)$.

Seventy-five percent of PV patients in our study had mucosal lesions, among them in $22 \%$ oral mucosa was the only location of the disease. In Northern Finland more than $90 \%$ of PV patients had mucous membrane involvement (11). We have found that these patients were apparently seeking medical help earlier that patients with exclusively skin involvement. It is established that nearly all patients with PV will develop oral lesions at some stage of the disease, which may cause severe pain and lead to the prevention of food intake and, in consequence, rapid weight loss (1).

Cardiological disorders were most frequent comorbidities in both groups, followed by autoimmune thyroiditis and psychiatric disorders. PF patients had significantly more frequent cardiological comorbidities (arterial hypertension and rhythm disturbances, mainly atrial fibrillation), history of internal organ malignancies and higher number of comorbidities than PV patients, which can be, at least in part, explained by older age of PF patients. Accordingly, the proportion of patients taking medications, and taking more than one medications, was higher among PF than PV patients.

In the literature, antihepertesives are the most important reported pemphigus-inducing drugs are, especially, ACE-inhibitors - ACEi (e.g. captopril, ramipril and lisinopril) and calcium channel blockers (e.g. nifedipine) (3). Because arterial hypertension was the most frequent co-morbidity in both groups, in consequence, antihypertensives (also ACEi and angiotensin II receptor blockers) were the most frequently taken medications. In contrast to previous study from Poland, we have found that PF patients took more antihypertensives that PV patients (with exception of calcium channel blockers), though statistical significant difference was established only for beta-blockers (13). Beta-blockers, however, are infrequently mentioned as medications increasing the risk of pemphigus (15). There are several hypothesis explaining drug-induced autoimmunity in pemphigus, among them: activation of acantholytic enzymes e.g. acethylocholin estherase by thiol radicals of ACEi, inhibition of enzymes responsible for cellcell adhesion e.g. keratinocyte transglutaminase $(1,3,13)$. Medications or their metabolites may bind proteins and form haptens and modify desmosomal autoproteins that results in forming of new antigens (13). The detailed analysis of these mechanisms is far behind the frame of this paper. Drug triggering, among other factors, should always be consider in every case of newly diagnosed, exacerbated or treatment-resistant pemphigus with antihypertensives playing the main role in clinical practice. ca schorzeniem o złożonej etiopatogenezie, spotykana w Brazylii, Kolumbii czy Tunezji występuje głównie wśród pracujących na zewnątrz mieszkańców terenów wiejskich $(2,14)$.

Siedemdziesiąt pięć procent pacjentów z pęcherzycą zwykłą miało zmiany w obrębie błon śluzowych. Wśród nich - u $22 \%$ była to jedyna manifestacja choroby. W badaniu z Północnej Finlandii zmiany śluzówkowe występowały u ponad $90 \%$ chorych z pęcherzycą zwykłą (11). Odnotowaliśmy, że pacjenci ci prawdopodobnie wcześniej szukają pomocy medycznej niż chorzy tylko ze zmianami w obrębie skóry bez zajęcia błon śluzowych. Niemal u wszystkich pacjentów z pęcherzycą zwykłą, w różnym okresie choroby dochodzi do rozwoju pęcherzy w obrębie błon śluzowych jamy ustnej, co sprawia dolegliwości bólowe, utrudnia lub uniemożliwia spożywanie posiłków i w konsekwencji prowadzi do utraty masy ciała (1).

Najczęstszymi schorzeniami współistniejącymi w chwili zachorowania na pęcherzyce były schorzenia układu krążenia w obu grupach, kolejnymi autoimmunologiczne zapalenie tarczycy i choroby psychiczne. Pacjenci z pęcherzycą liściastą mieli znacząco częściej choroby układu krążenia (nadciśnienie tętnicze i zaburzenia rytmu, głównie migotanie przedsionków), chorobę nowotworową w wywiadzie oraz większą liczbę chorób współistniejących niż pacjenci z pęcherzycą zwykłą, co może częściowo wynikać z ich starszego wieku. Konsekwentnie, proporcja osób przyjmujących leki oraz przyjmujących więcej niż jeden lek była wyższa wśród pacjentów z pęcherzycą liściastą niż zwykłą.

W piśmiennictwie, leki antyhypertensyjne, szczególnie ACE-inhibitory (ACEi, np. captopril, ramipril i lisinopril) oraz blokery kanału wapniowego (np. nifedipina) są lekami, które najczęściej powiązane są z możliwością indukowania pęcherzycy (3). Ponieważ nadciśnienie tętnicze było najczęściej współistniejącym schorzeniem w obu grupach pacjentów, leki przeciwnadciśnieniowe (w tym ACEi i inhibitory receptora angiotensyny II), przyjmowane były najczęściej. W przeciwieństwie do wcześniejszego badania z ośrodka poznańskiego, wykazaliśmy, że pacjenci z PF przyjmowali więcej leków antyhypertensyjnych niż pacjenci z PV (z wyjątkiem blokerów kanału wapniowego), chociaż istotność statystyczną różnic udało się ustalić tylko dla beta-blokerów (13). Ta grupa leków jest jednak rzadko wymieniana w kontekście zwiększania ryzyka wystąpienia pęcherzycy (15). Istnieje szereg hipotez, próbujących wyjaśnić rozwój autoimmunogenności stymulowanej lekami, w tym: aktywacja enzymów o działaniu akantolitycznym (np. esterazy acetylocholiny) pod wpływem grup tiolowych zawartych w ACEi, hamowanie enzymów biorących udział w przyleganiu komórek (np. transglutaminazy 
The association of PV and PF with other autoimmune diseases was found in several studies (reviewed in 2,3). We could confirm frequent autoimmune thyroiditis in both groups but other autoimmune disorders (rheumatoid arthritis, ulcerative colitis or Crohn disease) were not found. Some studies revealed association between pemphigus and psychiatric disorders (2). With except of paraneoplastic pemphigus, the association of pemphigus with malignancies is yet to be finally established.

The relapse of pemphigus may occur in up to 50 $\%$ of patients (1). Our study will be continued in order to find out factors associated with the risk of relapse that was noticed in about one third of patients. It was recently demonstrated that relapse of pemphigus was related to the lover initial prednisolone dose (16).

Long-term systemic steroids, usually administered together with other immunosuppressive agents remain the mainstay in the pemphigus treatment in many settings $(1,2,4,7)$. However, severe, even lifethreatening adverse events related to this therapy may develop in up to $65 \%$ of patients, which is in concordance with our findings (1).

\section{CONCLUSIONS}

The study confirms that females constitute majority of patients with pemphigus. Patients with PF are older that these with PV, they are more frequently inhabitants of rural areas, have more concomitant disorders, mostly of cardiovascular system as well as history of internal organ malignancies. Immunological remission appears to be achieved slower in PF than in PV patients. Relapse may occur in about one third of pemphigus patients. Because of frequents concomitant disorders, also these related to treatment of pemphigus, these patients require complex and multispecialistic health care. Pemphigus remains diagnostic and therapeutic challenge.

Acknowledgments: Authors thank dr Marta Koper for help in collecting data.

\section{REFERENCES}

1. Schmidt E, Kasperkiewicz M, Joly P. Pemphigus. Lancet. 2019;394(10201):882-94.

2. Kridin K. Pemphigus group: overview, epidemiology, mortality, and comorbidities. Immunol Res 2018;66: 255-70.

3. Tavakolpour S. Pemphigus trigger factors: special focus on pemphigus vulgaris and pemphigus foliaceus. Arch Dermatol Res 2018;301:95-106.

4. Kridin K, Zelberg-Sagi S, Bergman R. Pemphigus vulgaris and pemphigus foliaceus: differences in keratynocytów) $(1,3,13)$. Leki lub ich metabolity mogą wiązać się z białkami i modyfikować desmosomalne białka, tworząc nowe antygeny (13). Dokładna analiza tych mechanizmów przekracza ramy niniejszej publikacji. W każdym przypadku nowo zdiagnozowanej pęcherzycy, pogorszeniu jej obrazu klinicznego lub pęcherzycy opornej na standardowe leczenie należy wziąć pod uwagę potencjalną rolę przyjmowanych leków, szczególnie stosowanych w leczeniu nadciśnienia tętniczego.

Związek pęcherzycy zwykłej i liściastej z innymi schorzeniami o etiologii autoimmunologicznej wykazano w kilku badaniach (podsumowane w 2,3). Potwierdziliśmy dość częste współwystępowanie autoimmunologicznego zapalenia gruczołu tarczowego w obu grupach, ale inne schorzenia autoimmunologiczne (reumatoidalne zapalenie stawów, wrzodziejące zapalenie jelita grubego czy choroba Crohna) nie występowały. Badacze zwracają ponadto uwagę na powiązanie pęcherzyc $z$ chorobami psychicznymi (2). Poza przypadkami pęcherzycy paraneoplastycznej związek pęcherzycy z chorobami nowotworowymi pozostaje nie w pełni ustalony.

Uważa się, że nawroty pęcherzycy mogą wystąpić nawet u 50\% chorych (1). Badanie nasze będzie kontynuowane, między innymi, w celu zidentyfikowania czynników związanych z ryzykiem nawrotu pęcherzycy po uzyskaniu remisji klinicznej i immunologicznej. W jednej z ostatnich prac wykazano, że nawrót może wiązać się z wyjściowo niską dawką prednizonu (16).

Ogólnie przewlekle stosowane glikokortykosteroidy, najczęściej łącznie z innymi lekami immunosupresyjnymi, pozostają podstawą leczenia pęcherzyc w wielu ośrodkach $(1,2,4,7)$. Terapia ta może jednak wiązać się z działaniami niepożądanymi, nawet zagrażającymi życiu aż u 65\% pacjentów (1). Obserwowaliśmy również nowe schorzenia mogące wynikać ze stosowanej terapii u ponad połowy badanych pacjentów.

\section{WNIOSKI}

Badanie potwierdziło, że kobiety stanowią większość chorych z pęcherzycą. Pacjenci z PF są starsi niż z PV, częściej mieszkają na terenach wiejskich, mają więcej schorzeń współistniejących, z których najczęstsze są schorzenia układu sercowo-naczyniowego oraz wywiad w kierunku chorób nowotworowych. Remisja immunologiczna wydaję się być osiągana wolniej u chorych z PF niż z PV. U około jednej trzeciej chorych może dojść do nawrotu choroby. Pacjenci z pęcherzycą, ze względu na częste schorzenia wspólistniejące, także te, mogące być powiązane z jej leczeniem, wymagają złożonej i wielospecjalistycznej opieki medycznej. Pęcherzyce pozostają bardzo trudnym zagadnieniem diagnostycznym i terapeutycznym. 
epidemiology and mortality. Acta Derm Venereol 2017;97:1095-1099.

5. Serwin AB, Koper M, Flisiak I. Incidence of pemphigus vulgaris and pemphigus foliaceus in North-East Poland (Podlaskie Province) - a 15year (2001-2015) bicentric retrospective study. Int J Dermatol 2018;57:933-7.

6. Mihai S, Sitaru C. Immunopathology and molecular diagnosis of autoimmune bullous diseases. J Cell Mol Med 2007;11:462-81.

7. Patsatsi, A, Lamprou F, Kokolios M, et al. Spectrum of autoimmune bullous diseases in Northern Greece. A 4-year retrospective study and review of literature. Acta Dermatovenerol Croat 2017;25(3):195-201.

8. Jelti L, Cordel N, Gillibert A, et al. Incidence and mortality of pemphigus in France. J Invest Dermatol 2019;139:469-73.

9. Milinkovic, MV, Jankovic S, Medenica L, et al. Incidence of autoimmune bullous diseases in Serbia: a 20-year retrospective study. J Deutch Dermatol Ges 2016;14 (10):995-1005.

10. Hübner F, Recke A, Zillikens D, et al. Prevalence and age distribution of pemphigus and pemphigoid diseases in Germany. J Invest Dermatol 2016;136:2495-8.

11. Forsti A-K, Yuorre O, Laurila E, et al. Pemphigus foliaceus and pemphigus erythematosus are the most common subtypes of pemphigus in Northern Finland. Acta Derm Venereol 2019;99:1127-30.

12. Arduino PG, Brocoletti R, Carbone M, et al. Long-term evaluation of pemphigus vulgaris: a retrospective consideration of 98 patients treated in an oral medicine unit in north-west Italy. J Oral Pathol Med 2019;48: 406-12.

\section{Podziękowania}

Autorki dziękują dr Marcie Koper za pomoc w zbieraniu danych.

13. Pietkiewicz P, Gornowicz-Porowska J, BowszycDmochowska $\mathrm{M}$, et al. A retrospective study of antihypertensives in pemphigus: a still unchartered Odyssey particularly between thiols, amides and phenols. Arch Med Sci 2015;11(5):1021-7.

14. Hans-Filho G, Aoki V, Bittner NRH, et al. Fogo selvagem: endemic pemphigus foliaceus. Ann Bras Dermatol 2018;93(5):638-50.

15. Tatu AL, Elisei AM, Chioncel V, et al. Immunologic adverse reactions of $\beta$-blockers and the skin. Exp Ther Med. 2019;18(2):955-9.

16. Ujiie I, Ujiie $H$, Iwata $H$, et al. Clinical and immunological features of pemphigus relapse. $\mathrm{Br}$ J Dermatol 2019; 180(6):1498-505.

Received: 26.06.2020

Accepted for publication: 21.10.2020

Otrzymano:26.06.2020 r.

Zaakceptowano do publikacji: 21.10 .2020 r.

\section{Adres do korespondencji:}

Address for correspondence:

Ass. Prof. Agneszka B. Serwin

Department of Dermatology and Venereology

Medical University of Bialystok,

14, Zurawia St.

15-540 Bialystok, Poland

Phone: 857409559

e-mail: agabser@umb.edu.pl 